\title{
ILMUWAN SOSIAL BERKARAKTER UNTUK INDONESIA BERKEMAJUAN ${ }^{1}$ \\ Oleh Benni Setiawan \\ bennisetiawan@uny.ac.id \\ Fakultas Ilmu Sosial Universitas Negeri Yogyakarta
}

\begin{abstract}
Abstrak
Ilmu sosial seringkali dianggap kasta kedua dalam sistem saat ini, padahal ilmu sosial memberikan wajah humanis bagi kemanusiaan dan kebangsaan. Oleh karena itu ilmuwan sosial perlu menunjukkan pemikirannya untuk mewartakan kebenaran. Ilmuwan sosial selayaknya memiliki karakter khas yang menjadikannya tidak kalah saing dengan ilmuwan sains dan teknologi. Ilmuwan sosial mempunyai peran penting dalam membangun Indonesia. Tulisan ini mengemukakan paparan karakter ilmuwan sosial humaniora untuk dapat berkontribusi bagi pembangunan kemanusiaan dan kebangsaan. Setidaknya, ada satu karakter utama bagi seorang ilmuwan sosial humaniora ditambah tiga karakter lanjutan. Karakter utama bagi seorang ilmuwan sosial ialah cerdas berilmu dan puritan secara moral. Karakter kedua bagi seorang ilmuwan sosial adalah bersikap wasathiyyah. Karakter ketiga yang perlu dimilki oleh ilmuwan sosial adalah mampu bekerjasama dengan siapa pun. Karakter keempat adalah ilmuwun sosial dapat membangun pusat keunggulan.
\end{abstract}

Kata kunci: Ilmuwan Sosial, Cerdas dan Puritan secara Moral, Wasathiyyah, Kerjasama, Pusat Keunggulan

\section{Abstract}

Social science is often considered the second caste in the current system, whereas social science provides a humanist face for humanity and nationality. Therefore social scientists need to convey their thoughts to proclaim the truth. Social scientists should have a distinctive character that makes it no less competitive with science and technology scientists. Social scientists have an important role in building Indonesia. This paper presents the exposure of the character of social humanities scientists to be able to contribute to humanitarian and national development. At least, there is one main character for a humanities social scientist plus three others characters. The main character for a social scientist is intelligent and morally puritanical. The second character for a social scientist is being wasathiyyah. The third character that social scientists need to have is being able to work with anyone. The fourth character is social scientists could build a center of excellence.

Keywords: Social Scientists, Smart, Puritan Morally, Wasathiyyah, Cooperation, Center of Excellence

\footnotetext{
${ }^{1}$ Tulisan ini pernah dipresentasikan dalam Simposium Nasional Himpunan Indonesia untuk Pengembangan Ilmu-ilmu Sosial (HIPIIS). Grand Sahid Jaya Hotel, Jakarta, Selasa, 17 April 2018.
} 


\section{PENDAHULUAN}

Dalam pendidikan modern, humaniora semakin tersedak. Proses ini sudah lama berlangsung dan tampak di segala tahap pendidikan. Dengan perkembangan ilmu dan teknologi di zaman modern, jumlah fakultas di perguruan tinggi bertambah besar dan sekaligus peranan humaniora berkurang terus.

Padahal humaniora menghasilkan sesuatu yang penting. Yaitu wawasan yang luas, kapasitas untuk berubah, visi yang kreatif, kepekaan untuk implikasi sosial dan kultural, kemampuan untuk melihat the whole picture.

Di universitas - universitas Indonesia, posisi humaniora masih lemah. Infrastruktur akademis yang mendukung juga lemah. Universitas memberi prioritas mutlak kepada pengembangan ilmu dan teknologi (K. Bertens, 2009).

Hal ini terbukti dengan pengurangan jumlah beasiswa untuk studi ilmu humaniora pada tahun 2017. Pemerintah beralasan, bahwa penerima beasiswa LPDP dari latar belakang ilmu itu sudah banyak. Dan prioritas pemerintah sekarang adalah sains dan teknologi.
Berkurangnya jatah kursi beasiswa untuk studi ilmu sosial humaniora semakin diperparah oleh kondisi riset dan publikasi yang kurang memadai. Meminjam istilah Vedi R. Hadiz dan Daniel Dhakidae (2006) ilmu sosial humaniora seringkali masih terjebak pada "pembenaran" kekuasaan. Legitimasi kekuasaan oleh ilmu sosial humaniora itu seakan semakin mengecilkan langkah dalam mengembangkan dan membangun kemanusiaan. Ironisnya, ilmu sosial humaniora seringkali menjadi stempel bagi kebijakan pemerintah. Oleh karena itu, riset ilmu sosial humaniora seakan kering dan tak berdampak luas. Kecuali untuk memuaskan apa yang "dimaui" oleh pemilik kepentingan.

Menilik hal tersebut ilmuwan sosial perlu bangkit. Artinya, ilmuwan sosial selayaknya punya karakter khas yang menjadikannya tidak kalah saing dengan ilmuwan sains dan teknologi. Ilmuwan sosial mempunyai peran penting dalam membangun negeri ini. Dapat dibayangkan jika Republik ini tanpa ilmu sosial. Mungkin seorang Sukarnoinsinyur--tidak akan mampu menjadi pemimpin besar. Demikian pula Romo Mangunwijaya - arsitek--tidak akan melahirkan pendidikan pembebasan dengan membangun peradaban di 
bantaran Kali Code. Dan tanpa ilmu sosial seorang Tan Malaka tidak akan pernah menjadi pemimpin revolusioner Indonesia. Karirnya hanya akan mentok menjadi guru di kweekschool (Dendy Raditya Atmosuwito, 2018).

Oleh karenanya, ilmuwan dan ilmu sosial humaniora di Indonesia perlu mengepakkan sayap perubahan. Ilmuwan sosial yang konon sudah banyak jumlahnya selayaknya mempunyai karakter khas yang kemudian mereka dapat berbicara banyak di kontek lokal dan global.

Tulisan ini mengemukakan beberapa tawaran karakter ilmuwan sosial humaniora untuk dapat berkontribusi bagi pembangunan kemanusiaan dan kebangsaan. Setidaknya ada satu karakter utama bagi seorang ilmuwan sosial humaniora ditambah tiga karakter lanjutan. Empat karakter inilah yang akan mendorong ilmuwan sosial dapat berkontribusi dalam membangun Indonesia yang berkemajuan. Indonesia emas dengan penuh rahmat dari Tuhan Yang Maha Kuasa (baldatun thoyibatun wa rabbun ghofur, gemah ripah loh jinawi tata titi tentrem kerta raharja).

\section{PEMBAHASAN}

\section{Cerdas Berilmu; Puritan Secara Moral}

Karakter utama bagi seorang ilmuwan sosial ialah ia perlu menjadi seorang yang cerdas berilmu dan juga puritan secara moral. Cerdas berilmu berarti seorang ilmuwan sosial perlu mendalami ilmu dan kajian yang dikuasai secara tekun. Ketekunan itulah yang akan mengantarkan seorang ilmuwan cerdas berilmu. Ia tidak sekadar cerdas secara intelektual, namun juga mempunyai keunggulan dan kedalaman ilmu. Meminjam istilah al-Quran inilah karakter ulul albab (Q.S. Ali Imran, 3: 190-191).

Ulul albab sebagaimana ayat di atas digambarkan sebagai orang yang tidak lelah dalam mengembangkan ilmu pengetahuan. Ia selalu konsisten dalam kata dan laku. Ia pun selalu memikirkan tanda-tanda kekuasaan Allah dalam berbagai keadaan dan situasi. Mereka pun selalu tertantang untuk mengurai persoalan sosial dengan berbagai pendekatan. Saat berbagai pendekatan itu telah diupayakan sedemikian rupa, namun ia tidak mampu mengurai masalah sosial, ia pun tidak kunjung putus asa. Ia selalu berusaha, berkhidmat, dan bertawakal kepada Allah. 
Lebih lanjut, cerdas berilmu berawal dari proses pemahaman diri dan lingkungan yang bermula pada pemahaman atas kemanusiaannya. Driyarkara menyebut keluruhan manusia sebagai pribadi terletak pada kedaulatan atas dirinya sendiri. Untuk memberi gambaran tentang kemuliaan ini kita pakai istilah "bersemayam". Manusia bersemayam dalam dirinya sendiri, menentukan dirinya sendiri, memastikan perbuatannya dengan merdeka, menentukan nasibnya sendiri dengan memilih sendiri, bebas merdeka dari paksaan dan tekanan (A Sudiarja, G. Budi Subanar, St. Sunardi, T Sarkim (Peny), 2006).

Manusia perlu merdeka sebagaimana fitrah kemanusiaan. Manusia merdeka akan mampu melakukan apa yang mereka inginkan. Manusia merdeka pun mendorong terjadinya transformasi individu menuju transformasi sosial. Manusia merdeka pun tidak akan menjadi penguasa dan atau budak bagi yang lain. Pasalnya, mereka memahami posisi dan peran masing-masing dalam jagat raya ini.

Dalam proses itu, Driyakara menulis manusia memang dapat menghanyutkan diri dengan menurut kecenderungan-kecenderungan yang rendah. Jika itu terjadi, manusia menyerahkan kedaulatannya, ia mengkhianati tahtanya, memperbudakkan diri. Di situ manusia mempergunakan kemerdekaannya untuk mengikat diri, untuk menjerumuskan diri. Dengan ini tampaklah kiranya apakah yang dimaksudkan dengan "berdaulat", "bertahta", "kediri-sendirian". Jika manusia menjalankan hidupnya menurut dorongan-dorongan yang luhur sambil mengalahkan dorongan-dorongan yang rendah, itulah artinya manusia bertahta dan berdaulat. Dialah sendiri yang menentukan, tidak dibelenggu oleh faktor-faktor jasmani yang buta (A Sudiarja, G. Budi Subanar, St. Sunardi, T Sarkim (Peny), 2006).

Ilmuwan sosial cerdas berilmu perlu memahami posisi dirinya dalam proses interaksi sosial. Pemahaman diri inilah yang akan mengukuhkan ilmuwan sosial pada posisi terhormat. Posisi di mana ia diangkat derajatnya oleh Tuhan dalam mengembang amanat keumatan dan kemanusiaan (Q.S. Al-Mujadilah, 58: 11).

Ilmuwan sosial pun senantiasa mendasarkan ilmunya pada proses kreatif inovatif. Proses itu akan mampu bertahan di tengah era disruptif (disruption) saat ini. Era di mana kemapanan akan 
tergantikan oleh hal-hal baru. Era ini membutuhkan orang-orang yang sigap dan tangkas dalam membaca perubahan zaman.

Ilmuwan sosial dalam posisi seperti ini-berbekal cerdas berilmu-akan mampu membaca tanda zaman dengan baik. Ia tidak akan hanyut dalam laju perubahan zaman (ngeli ning ora keli). Ia pun dapat memenangkan perubahan zaman tanpa harus merasa paling hebat dan memandang rendah yang lain. Menang tanpa ngasorake, meminjam istilah Sosrokartono.

Setelah ilmuwan sosial mempunyai kapasitas itu, kecakapan lain yang harus melekat (menyatu) adalah ia selayaknya puritan dalam moral. Puritan dalam moral ini berarti ia tidak boleh melacurkan cerdas ilmunya untuk kepentingan uang dan kekuasaan. Ilmuwan sosial perlu menjadi orang yang berdikasi tinggi dalam menjadi muruah dan martabat dirinya.

Proses itu memantapkan peran dan posisi ilmuwan sosial sebagai garda terdepan perubahan sosial. Perubahan sosial hanya akan berhasil saat didukung oleh orang-orang yang mempunyai komitmen moral yang tinggi. Puritan dalam moral akan menyelamatkan ilmuwan sosial dari cemooh menjual ilmu dengan harga yang murah. Komitmen pada pijakan itu pun dapat menepis kritik yang dilayangkan oleh Pramoedya Ananta Toer.

Pram menulis, "Di Hindia ini, tuan, sejauh yang kuperhatikan, begitu banyak terpelajar mendapat jabatan dalam dinas Gubermen, dia berhenti sebagai terpelajar. Kontan dia ditelan oleh mentalitas umum priyayi: beku, rakus, gila hormat, dan korup" (Pramoedya Ananta Toer, 2010a).

Guratan dalam seri "Tetralogi Pulau Buru", Jejak Langkah itu adalah kritik Pram terhadap ilmuwan sosial yang seringkali tak mempunyai komitmen moral dalam mengemban amanat keilmuan. Saat mereka telah masuk dalam pusaran kekuasaan, mereka akan berubah 180 persen. Mereka akan menjadi seorang yang jauh dari komitmen ilmu sebagai pembebasan. Alih-alih mengembangkan ilmu, tidak ilmuwan sosial yang masuk dalam kekuasaan lupa diri bahkan kalap dalam perebutan kuasa kehormatan.

Ilmuwan sosial perlu puritan dalam moral agar ia tidak mudah terjebak dalam pragmatisme. Pragmatisme hanya akan mendorong ilmuwan sosial masuk dalam kubangan gelap kenistaan pribadi. Mereka akan sulit bangkit karena 
terlanjur berlumuran noda. Ilmu yang mereka bangun dan tekuni hanya akan menjadi bahan olok-olok saat keberpihan jauh dari nilai kemanusiaan dan keadilan.

Nilai kemanusiaan dan keadilan perlu menjadi tonggak bagi siapa pun yang mengaku sebagai ilmuwan sosial atau yang lain. Saat orientasi kemanusiaan dan keadilan berada dalam diri sejak dalam pikiran-meminjam istilah Pram-maka ia akan menjadi lentera yang terang. Ia akan menjadi penunjuk jalan bagi orang-orang yang tersesat; memberi kabar gembira pada mereka yang sedang sedih; dan menjadi penyuara kebenaran disaat semua bungkam dalam persekutuan dusta.

Lebih dari itu, nilai kemanusiaan dan keadilan perlu dipegang teguh oleh ilmuwan sosial sebagai upaya mewujudkan cita Pancasila. Cita Pancasila yang termuat dalam Sila Kedua dan Kelima itu merupakan ruh bangsa. Ilmuwan sosial berkewajiban menjaga dan mendorong terwujudnya mantra bangsa itu. Mantra itu hanya dapat diemban oleh mereka yang mempunyai karakter puritan dalam moral.

\section{Karakter Moderat}

Karakter kedua bagi seorang ilmuwan sosial adalah bersikap wasathiyyah (Q.S. Al-Baqarah, 2: 143). Wasathiyyah berarti tengah (moderat). Artinya, seorang ilmuwan sosial perlu menarik diri ke tengah dalam pergumulan zaman. Menarik diri ke tengah itu pun merupakan perwujudan dari nilai keadilan. Berdiri di tengah bukan berarti tidak mempunyai keberpihakan. Selain keberpihakan pada kemanusiaan dan keadilan, ilmuwan sosial perlu berpijak untuk kemaslahatan bersama (orang banyak).

Ilmuan sosial akan mampu bersikap adil saat ia memosisikan diri berada di tengah, bukan di kiri atau di kanan. Artinya, karakter ilmuwan sosial adalah mereka yang dapat menempatkan pendapat dan tindakan dalam porsi yang seimbang.

Karakter masuk ke tengah akan dapat mengembangkan humanisasi. Artinya, saat seseorang mampu memosisikan diri di tengah ia akan menjadi hakim yang baik. Ia akan mampu memandang persoalan dengan lebih jernih tanpa harus terkontaminasi oleh bisikan atau rayuan pihak kanan dan atau kiri. 
Saat ilmuwan sosial mampu menarik diri ke tengah ia akan mengemban amanat kerukunan. Meminjam istilah Ahmad Syafii Maarif, mantra kerukunan adalah bersaudara dalam perbedaan, dan berbeda dalam persaudaraan.

Mantra itu perlu kembali diingat dan menjadi kerja kemanusiaan ilmuwan sosial di tengah semakin mengguritanya hoaks dan ujaran kebencian. Hoaks dan ujaran kebencian telah banyak memakan korban.

Ilmu(wan) sosial perlu kembali menjadi rujukan dalam mengurai masalah itu. Saat ilmu sosial mundur, maka Indonesia akan masuk dalam fase kritis darurat hoaks dan ujaran kebencian (Kompas. 16/4/2018). Hoaks dan ujaran kebencian dapat diurai saat ilmuwan sosial secara lantang menyuarakan arti penting ungkapan Buya Syafii di atas.

Perbedaan pendapat selayaknya menjadikan kita tetap bersaudara. Persaudaraan hanya akan dapat dibangun atas dasar saling kenal, memahami, dan kerelaan. Ilmu sosial yang bermuara pada pemanusiaan adalah perekat itu semua. Ilmu sosial yang dikembangkan secara sistematis akan memperhalus budi manusia. Manusia tidak akan mudah terjerembab dalam homo homini lupus.
Manusia akan menuju pada pemanusiaan sejati (homo homini socius).

Ilmu sosial mendorong manusia menuju fitrah dan kesejatian hidup. Fitrah dan kesejatian hidup itu hanya dapat diemban oleh mereka yang selalu ada di tengah. Artinya, mereka menyuarakan suara keberpihakan untuk kemaslahatan umum tidak disertai dengan rasa benci.

Mereka yang berada di tengah akan mampu menahan diri saat diserang. Mereka tetap bertahan sembari terus menyuarakan kebenaran.

Posisi masuk ke tengah juga akan menjadikan ilmuwan sosial mempunyai peran strategis dalam mengembangkan kajian teori (konseptual) dan praktis dalam mengurai masalah kemanusiaan. Keberadaannya mereka di tengah pun akan merekat persatuan Indonesia sebagaimana amanat Sila Ketiga Pancasila.

Saat amanat itu teremban dengan baik, maka hoaks dan ujaran kebencian tidak akan pernah laku (berkembang). Pasalnya, ilmuwan sosial telah berhasil mentransformasikan diri menjadi pemersatu. Kematian hoaks dan ujaran kebencian merupakan buah dari hasil komitmen dan konsistensi ilmuwan sosial untuk berada di tengah. 


\section{Kerjasama dan Sinergi}

Karakter ketiga yang perlu dimilki oleh ilmuwan sosial adalah mampu bekerjasama dengan siapa pun. Era revolusi 4.0 mensyaratkan adalah big colaboration. Big colaboration membutuhkan orang-orang yang bisa bekerjasama dengan siapa saja dan dimana saja.

Melalui kerjasama hal yang berat akan menjadi ringan. Kerjasama akan menggusur kesulitan dan beban berat. Kerjasama pun akan semakin memperluas jejaring sosial sekaligus mengembangkan persaudaraan sejati.

Kunci keberhasilan dalam kerjasama adalah mengelola emosi. Orang-orang yang mampu mengelola emosi (mempunyai kematangan emosional) akan dapat bekerjasama dengan siapa saja. Ia tidak merasa paling pintar. Namun, semua saling menguatkan satu sama lain.

Lebih dari itu, kerjasama juga akan memudahkan langkah ilmuwan sosial membangun masyarakat. Ali Shariati (1995) mengungkapkan bahwa cendekiawan mempunyai tanggung jawab penting dalam menciptakan dan mengalihkan fakta-fakta-fakta-fakta yang positif dan konstruktif, beserta fakta-fakta dunia dewasa ini-ke dalam kesadaran generasi kita dewasa ini.

Sebagai cendekiawan kita tidak diharapkan sekadar menjadi penonton. Peranan cendekiawan adalah membantu masyarakat agar berkembang lebih cepat dengan cara mengenalinya, mempengaruhinya, dan memanfaatkannya, serta mengaktifkan organ-organ dan hubungan sosialnya, sehingga ia tidak tertinggal di belakang dunia modern. Membangun masyarakat terletak dalam usahanya, dalam kehidupannya yang selalu dinamis, jika tidak demikian pasti ia akan menyerah pada determinisme historis yang melenyapkan kepribadian dan komitmennya (Ali Shariati, 1996).

Komitmen berbagi peran dalam bingkai kerjasama perlu didukung oleh sinergi gerak. Sinergi gerak itulah yang akan semakin menguatkan jejaring sosial ilmuwan sosial. Sinergi antar bidang kehidupan pun mendorong munculnya pusat-pusat keunggulan.

\section{Pusat Keunggulan}

Inilah karakter terakhir ilmuwan sosial. Pusat keunggulan sebagaimana catatan di atas hanya akan mampu mewujud saat semua telah terbangun kesadaran kerjasama dan sinergi. 
Pusat keunggulan demikian bukanlah menara gading. Pusat keunggulan merupakan rumah-rumah peradaban yang dapat diakses dengan mudah oleh masyarakat. Melalui pusat keunggulan ilmuwan sosial akan menyantu dalam denyut kehidupan masyarakat.

Ignas Kleden sebagaimana dikutip oleh Daniel Dhakidae (2003), menulis, setidaknya ada tiga model ilmuwan sosial. Pertama sebagai intelektual, seorang ilmuwan sosial tetap mempertahankan dialognya yang kontinu dengan masyarakat sekitarnya dalam suatu keterlibatan yang intensif dan sensitif. Kedua, sebagai ilmuwan, dia akan berusaha memperluas wawasan teoritis dan keterbukannya kepada kemungkinan dan penemuan baru dalam bidang ahlinya. Ketiga, sebagai seorang teknikus, dia tetap menjaga keterampilannya memakai instrumen yang tersedia dalam disiplin yang dikuasainya. Dua peran terakhir memungkinkan dia menjaga martabat ilmunya, sedangkan peran pertama mengharuskannya untuk turut menjaga martabat manusia.

Pusat keunggulan pun menjadi bangunan infrastruktur kultural masyarakat yang kokoh. Namun perlu diingat catatan Ali Shariati (1996). Shariati menulis setiap mazhab atau ideologi yang gagal mendaratkan dirinya di atas infrastruktur kultural masyarakat tidak akan jauh berbeda dengan sebuah buku yang populer yang disimpan dalam perpustakaan untuk bacaan publik. Sarjana, mahasiswa, dan pembacapembaca tetentu mungkin membaca buku tersebut, atau ribuan naskah dari buku tersebut mungkin diterbitkan. Namun, massa tetap tidak berubah. Kaum intelektual akan terasing dari masyarakatnya dan hal ini merupakan bahaya terbesar. Jika masyarakat tetap menderita akibat isolasi kaum intelektualnya, maka masyarakat tersebut tidak akan pernah dapat mengakhiri keadaannya yang dekaden secara terus menerus, walaupun dapat saja masyarakat itu memiliki pemikir-pemikir raksasa yang diakui oleh dunia.

Oleh karena itu, pusat keunggulan perlu di bangun di banyak tempat. Pengkajian keilmuan sosial perlu bersemi di setiap kampus di Indonesia. Misalnya, apa yang telah kami rintis di Fakultas Ilmu Sosial (FIS) Universitas Negeri Yogyakarta (UNY) melalui Majelis Studi Ilmu-ilmu Sosial Keindonesiaan (MASISKA). Lembaga ini lahir sebagai respon jawaban kegelisahan semakin 
tersisihnya ilmu sosial. Melalui MASISKA diharapkan FIS UNY mempunyai ciri khas dan menjadi pusat keunggulan. Pusat keunggulan itu setidaknya mewakili persemaian (tumbuhnya) kajian ilmu-ilmu sosial khas keindonesiaan. Melalui serangkaian tahapan, kami bermimpi bahwa pada tahun 2025 MASISKA menjadi acuan pengembangan paradigma ilmu sosial keindonesiaan dalam keilmuan dan pembelajaran baik di dalam negeri maupun luar negeri.

MASISKA ingin menjadi bagian integral kemerdekaan kaum intelektual. Sebagaimana catatan Pram dalam Rumah Kaca (2010b). "Kaum terpelajar pribumi mengumumkan kebangkitannya di koran dan majalah-majalah, dalam bahasabahasa yang dapat mereka gunakan. Persoalannya menjadi umum, diketahui banyak orang, tidak hanya menjadi persoalan diri semata. Koran dan majalah telah melahirkan semangat demokratis tanpa semau Gubermen".

Kaum terpelajar pribumi (ilmuwan sosial) dapat berkontribusi positif dalam pengembangan keilmuan tanpa harus tersandera oleh kepentingan jangka pendek. Mewujudkan kebangkitan kaum terpelajar pribumi ala Pram dapat ditempuh melalui penelitian yang serius.

\section{Daniel Dhakidae}

(2003) mengungkapkan para ilmuwan sosial dianjurkan untuk mengadakan penelitian yang tidak terbatas pada penelitian jangka pendek yang sifatnya segera terpakai. Akan tetapi, juga memperhatikan hal-hal yang basis dan berjangka panjang.

Penelitian basis dan berjangka panjang akan memperpanjang nafas ilmuwan sosial memproduksi gagasan dan ide. Nafas panjang itulah yang dalam bahasa Kuntowijoyo sebagai proses humanisasi. Pak Kunto menyebut humanisasi adalah memanusiakan manusia. Manusia sekarang mengalami proses dehumanisasi karena masyarakat industrial menjadikan kita sebagai bagian dari masyarakat abstrak tanpa wajah kemanusiaan. Kita mengalami objektivasi ketika berada di tengah-tengah mesin politik dan mesin-mesin pasar. Ilmu dan teknologi juga telah membantu kecenderungan reduksionistik yang melihat manusia secara parsial (Kuntowijoyo, 1991).

Saat setiap kampus atau gabungan kampus mempunyai pusat-pusat keunggulan, maka ilmu sosial akan dapat eksis. Ilmu sosial akan menjadi rujukan utama mengurai proses kemanusiaan sebagaimana di Eropa sekitar abad ke-13. 
Saat itu ilmu sosial humaniora memainkan peran sentral. Peran sentral itu mewujud dalam pelembagaan studi sosial humaniora menjadi tahap awal seluruh pendidikan tinggi (K. Bertens, 2009).

Saat setiap kampus mempunyai pusat keunggulan, maka elan vital ilmu sosial bagi kehidupan manusia berada pada taraf keadaban-bonnum commune meminjam istilah Habermas. Manusia akan kembali pada fitrahnya sebagai pemimpin (khalifah fi al-ardhi) dan penjaga harmoni antar sesama hidup.

Pusat keunggulan pun perlu diinisiasi berbasis kekhasan setiap kampus. Kekhasan inilah yang akan menguatkan ilmu-ilmu sosial. Bangunan kekhasan yang membentang dari ujung Barat sampai Timur menjadi potret Indonesia berkemajuan.

\section{KESIMPULAN}

Indonesia berkemajuan adalah potret di mana ilmu-ilmu sosial menjadi laku bangsa. Ilmu sosial menjadi rujukan utama bagi pemecahan masalah bangsa dan negara. Indonesia berkemajuan menjadi mimpi (anggitan) bagi terwujudnya cita luhur Pancasila dan UUD 1945. Semoga bermanfaat.

\section{Daftar Pustaka}

Alquran dan Terjemahnya. 2014. Jakarta. Kemenag R.I.

Ali Shariati. (1996). Tugas Cendekiawan Muslim. Jakarta: Raja Grafindo Persada.

Daniel Dhakidae. (2003). Cendekiawan dan Kekuasaan dalam Negara Orde Baru. Jakarta: Gramedia Pustaka Utama.

Dendy Raditya Atmosuwito. (2018). "Kebijakan LPDP dan Nasib Ilmu Sosial Humaniora Kita". Tirto.id. 4 Januari.

Bertens. K (2009). Perspektif Etika Baru, 55 Esai tentang Masalah Aktual. Yogyakarta: Kanisius.

Kompas. "Ilmu Sosial Mundur Picu Hoaks", Senin, 16/4/2018.

Kuntowijoyo. (1991). Paradigma Islam Interpretasi untuk Aksi. Bandung: Mizan.

Pramoedya Ananta Toer. (2010a). Jejak Langkah. Jakarta: Lentera Dipantara.

Pramoedya Ananta Toer. (2010b). Rumah Kaca. Jakarta: Lentera Dipantara.

Sudiarja, A., G. Budi Subanar, St. Sunardi, T Sarkim (Peny). (2006). Karya Lengkap Driyarkara, Esaiesai Filsafat Pemikir yang Terlibat Penuh dalam Perjuangan Bangsanya. Jakarta: Gramedia Pustaka Utama.

Vedi R. Hadiz dan Daniel Dhakidae. (2006). Ilmu Sosial dan Kekuasaan di Indonesia. Jakarta: Equinox. 